\title{
HYPOXIC REGULATION OF THE EXPRESSION OF CELL PROLIFERATION RELATED GENES IN U87 GLIOMA CELLS UPON INHIBITION OF IRE1 SIGNALING ENZYME
}

\author{
O. H. MINCHENKO', D. O. TSYMBAL ${ }^{1}$, D. O. MINCHENKO ${ }^{1,2}$, \\ O. O. RIABOVOL ${ }^{1}$, O. O. RATUSHNA ${ }^{1}$, L. L. KARBOVSKYI \\ ${ }^{1}$ Palladin Institute of Biochemistry, National Academy of Sciences of Ukraine, Kyiv; \\ e-mail: ominchenko@yahoo.com; \\ ${ }^{2}$ Bohomolets National Medical University, Kyiv, Ukraine
}

We have studied the effect of inhibition of IRE1 (inositol requiring enzyme 1), which is a central mediator of endoplasmic reticulum stress and a controller of cell proliferation and tumor growth, on hypoxic regulation of the expression of different proliferation related genes in U87 glioma cells. It was shown that hypoxia leads to up-regulation of the expression of IL13RA2, CD24, ING1, ING2, ENDOG, and POLG genes and to down-regulation - of KRT18, TRAPPC3, TSFM, and MTIF2 genes at the mRNA level in control glioma cells. Changes for ING1 and CD24 genes were more significant. At the same time, inhibition of IRE1 modifies the effect of hypoxia on the expression of all studied genes. In particular, it increases sensitivity to hypoxia of the expression of IL13RA2, TRAPPC3, ENDOG, and PLOG genes and suppresses the effect of hypoxia on the expression of ING1 gene. Additionally, it eliminates hypoxic regulation of KRT18, CD24, ING2, TSFM, and MTIF2 genes expressions and introduces sensitivity to hypoxia of the expression of BET1 gene in glioma cells. The present study demonstrates that hypoxia, which often contributes to tumor growth, affects the expression of almost all studied genes. Additionally, inhibition of IRE1 can both enhance and suppress the hypoxic regulation of these gene expressions in a gene specific manner and thus possibly contributes to slower glioma growth, but several aspects of this regulation must be further clarified.

K e y w or d s: mRNA expression, endoplasmic reticulum stress, IL13RA2, KRT18, CD24, ING1, ING2, MYL9, BET1, TRAPPC3, ENDOG, POLG, TSFM, MTIF2, IRE1 inhibition, hypoxia, glioma cells.

$\mathrm{T}$ he IL13RA2 (interleukin 13 receptor, $\alpha 2$ ), CD24 (signal transducer CD24 molecule), ING1 (inhibitor of growth family, member 1), ING2, ENDOG (endonuclease G) and many others play an important role in the regulation of numerous metabolic and proliferative processes [1-5]. It is well known that these genes play important roles in control of tumorigenesis [3, 5-7]. The IL13RA2 gene is often overexpressed in glioma and other tumors [1, 3]. CD24 encodes a sialoglycoprotein that modulates growth and differentiation signals [4]. The ING1 and ING2 genes encode tumor suppressor proteins that can induce cell growth arrest and apoptosis $[5,7]$. The ING1 is a nuclear protein that physically interacts with the tumor suppressor protein TP53 and is a component of its signaling pathway. Reduced expression and rearrangement of this gene have been detected in various cancers [8, 9]. Moreover, ING1 stabilizes p53 by inhibiting polyubiquitination [10].
KRT18 (keratin 18) contributes to decreased malignancy of non-small cell lung carcinoma and is directly regulated by EGR1 [11]. There is data that the decreased expression of MYL9 (myosin, light chain 9 , regulatory) may play an important role in tumor progression of prostate cancer [6]. BET1 (Bet1 Golgi vesicular membrane trafficking protein) and TRAPPC3 (trafficking protein particle complex 3) participate in vesicular transport from the endoplasmic reticulum to the Golgi complex and are also possibly involved in the endoplasmic reticulum stress responsible transport of unfolded proteins [12]. The ENDOG, POLG (DNA directed polymerase gamma), TSFM (Ts mitochondrial translational elongation factor), and MTIF2 (mitochondrial translational initiation factor 2) genes encode mitochondrial proteins, which are related to the control of mitochondrial genome function as well as to cell proliferation [13-17]. Moreover, ENDOG regulates an integral 
network of apoptotic endonucleases, which appear to act simultaneously before and after cell death by destroying the host cell DNA $[13,18]$.

Tumor growth is tightly associated with the endoplasmic reticulum stress response-signalling pathway and hypoxia, which are linked to the neovascularization and cell death processes [19-23]. The endoplasmic reticulum has an essential position as a signal integrator in the cell and is instrumental in the different phases of tumor progression because the signaling pathways elicited by endoplasmic reticulum stress sensors are connected to metabolic pathways and to other plasma membrane receptor signaling networks [24-26]. Multiple studies have clarified the link between cancer and endoplasmic reticulum stress, which controls different processes including cell proliferation and surviving as well as circadian rhythms [20, 21, 27, 28]. The IRE1 (inositol requiring enzyme 1) is a central mediator of the unfolded protein response and its inhibition leads to suppression of tumor growth through down-regulation of the angiogenesis and proliferation processes [29-31]. It contributes to changes in the expression profile of many regulatory genes resulting in proliferation, angiogenesis, and apoptosis [30, 31, 42]. The endoribonuclease of IRE1 is responsible for degradation of a specific subset of mRNAs and splicing of the XBP1 (X-box binding protein 1) transcription factor mRNA for control of the expression of unfolded protein response-specific genes [32-34].

Ablation of IRE1 function results in a significant anti-proliferative effect in glioma growth through down-regulation of key pro-angiogenic and pro-proliferative factors and up-regulation of tumor suppressor genes as well as through modification of hypoxic regulation of these genes [30-31, 36-38]. However, the executive mechanisms of the exhibited anti-proliferative effects of IRE1 inhibition are not yet known. It is possible that this anti-proliferative effect is also mediated by IL13RA2, KRT18, CD24, ING1, ING2, MYRL2, BET1, TRAPPC3, ENDOG, POLG, TSFM, and MTIF2 proteins, which are integrated into the unfolded protein response signaling pathways and regulate cell proliferation [3-6, 9, 11, 15]. Possible involvement of IL13RA2, KRT18, CD24, ING1, ING2, MYRL2, BET1, TRAPPC3, ENDOG, $P O L G$, TSFM, and MTIF2 genes was made evidently pertinent through transcriptomic analysis of U87 glioma cells expressing the dominant-negative mutant of IRE1 [30].

The main goal of this study was to investigate the expression levels of proliferation related genes
(IL13RA2, KRT18, CD24, ING1, ING2, MYRL2, BET1, TRAPPC3, ENDOG, POLG, TSFM, and MTIF2) in U87 glioma cell line and its subline without signaling enzyme IRE1 function under hypoxic conditions for evaluation of their possible significance for the control of glioma cell proliferation through IRE1 mediated endoplasmic reticulum stress signaling.

\section{Materials and Methods}

Cell Lines and Culture Conditions. The glioma cell line U87 (HTB-14) was obtained from ATCC (USA) and grown in high glucose (4.5 g/l) Dulbecco's modified Eagle's minimum essential medium (DMEM; Gibco, Invitrogen, USA) supplemented with glutamine $(2 \mathrm{mM}), 10 \%$ fetal bovine serum (Equitech-Bio, Inc., USA), penicillin (100 units/ml; Gibco, USA) and streptomycin $(0.1 \mathrm{mg} / \mathrm{ml}$; Gibco $)$ at $37{ }^{\circ} \mathrm{C}$ in a $5 \% \mathrm{CO}_{2}$ incubator.

In this study we used sublines of U87 glioma cells, which were described previously [9, 40, 41, 48]. One subline was obtained by selection of stable transfected clones with overexpression of vector pcDNA3.1, which was used for creation of dnIRE1 (dominant/negative IRE1). This untreated subline of glioma cells (control glioma cells) was used in the study of the effect of hypoxia on the expression level of IL13RA2, KRT18, CD24, ING1, ING2, MYL9, BET1, BET3/TRAPPC3, ENDOG, POLG, TSFM, and MTIF2 genes. Second subline was obtained by selection of stable transfected clone with overexpression of IRE1 dominant/negative construct (dnIRE1) and consequent inhibition of both protein kinase and endoribonuclease activities of this signaling enzyme (clone 1C5) [40]. The expression levels of studied genes in these two sublines of glioma cells were compared with corresponding levels in cells, transfected by vector or by dnIRE1. The efficiency of IRE1 suppression in this glioma cell subline was estimated previously [30, 31] by determining the expression level of spliced XBP1, a key transcription factor in the IRE1 signaling, and the level of the phosphorylated IRE1 isoform in cells treated by tunicamycin $(0.01 \mathrm{mg} / \mathrm{ml}$ during $2 \mathrm{~h})$. Both sublines of glioma cells used in this study were grown with addition of geneticin (G418) while these cells carry an empty pcDNA3.1 vector or dnIRE1 construct.

To model hypoxia the culture plates were incubated in special chamber with 3\% oxygen, $92 \%$ nitrogen, and 5\% carbon dioxide for $16 \mathrm{~h}$.

RNA isolation. Total RNA was extracted from glioma cells using Trizol reagent according to man- 
ufacturer protocol (Invitrogen, USA) as described previously [31]. The RNA pellets were washed with $75 \%$ ethanol and dissolved in nuclease-free water. For additional purification, RNA samples were reprecipitated with $95 \%$ ethanol and re-dissolved again in nuclease-free water. RNA concentration and spectral characteristics were measured using NanoDrop spectrophotometer ND1000 (PEQLAB, Biotechnologie $\mathrm{GmbH}$ ).

Reverse transcription and quantitative PCR analysis. QuaniTect Reverse Transcription Kit (QIAGEN, Germany) was used for cDNA synthesis according to manufacturer protocol. The expression levels of IL13RA2, KRT18, CD24, ING1, ING2, MYRL2, BET1, TRAPPC3, ENDOG, POLG, TSFM and MTIF2 mRNAs as well as ACTB mRNA were measured in U87 glioma cells by real-time quantitative polymerase chain reaction using Mx 3000P QPCR (Stratagene, USA) or „RotorGene RG-3000” qPCR (Corbett Research, Germany) and Absolute qPCR SYBRGreen Mix (Thermo Fisher Scientific, ABgene House, UK). Polymerase chain reaction was performed in triplicate using specific primers, received from Sigma-Aldrich, USA.

For amplification of IL13RA2 (interleukin 13 receptor, $\alpha 2)$ cDNA we used forward (5'- TCTTGGAAACCTGGCATAGG- $3^{\prime}$ and reverse (5'-TCTGATGCCTCCAAATAGGG-3') primers. The nucleotide sequences of these primers correspond to sequences 591-610 and 742-723 of human IL13RA2 cDNA (NM_000640). The size of amplified fragment is $152 \mathrm{bp}$. The amplification of KRT18 (keratin 18 , type I) cDNA was performed using two oligonucleotides primers: forward $-5^{\prime}-$ CACAGTCTGCTGAGGTTGGA-3' and reverse - 5'-GAGCTGCTCCATCTGTAGGG-3'. The nucleotide sequences of these primers correspond to sequences 966-985 and 1129-1110 of human KRT18 cDNA (NM_000224). The size of amplified fragment is $164 \mathrm{bp}$.

The amplification of CD24 (CD24 molecule; Signal Transducer CD24) cDNA was performed using two oligonucleotides primers: forward $-5^{\prime}-$ AACTAATGCCACCACCAAGG-3' and reverse 5'-CCTGTTTTTCCTTGCCACAT-3'. The nucleotide sequences of these primers correspond to sequences 590-609 and 777-758 of human CD24 cDNA (NM_013230). The size of amplified fragment is $169 \mathrm{bp}$. For amplification of MYL9 (myosin, light chain 9, regulatory), also known as MYRL2 (myosin regulatory light chain 2) cDNA we used forward (5'-ACCCCACAGACGAATACCTG-3' and reverse
(5'-CCGGTACATCTCGTCCACTT-3') primers. The nucleotide sequences of these primers correspond to sequences 285-304 and 526-507 of human MYL9 cDNA (NM_006097). The size of amplified fragment is $242 \mathrm{bp}$.

For amplification of ING1 (inhibitor of growth family, member 1) cDNA we used forward (5'CCAAGGGCAAGTGGTACTGT-3' and reverse (5'-CTGCCATCCCTATGAAAGGA-3') primers. The nucleotide sequences of these primers correspond to sequences $1601-1620$ and 1845-1826 of human ING1 cDNA (NM_005537). The size of amplified fragment is $245 \mathrm{bp}$. The amplification of ING2 (inhibitor of growth family, member 2) cDNA was performed using two oligonucleotides primers: forward - 5'-ACGTCTACAGCAGCTTCTCC- $3^{\prime}$ and reverse - 5'-TGCGGGGTCTTCTTGAAGAT-3'. The nucleotide sequences of these primers correspond to sequences 369-388 and 589-570 of human ING2 cDNA (NM_001564). The size of amplified fragment is $221 \mathrm{bp}$.

For amplification of BET1 (Bet1 Golgi vesicular membrane trafficking protein) cDNA we used forward ( $5^{\prime}-$ AGAAGTTGGTGTTTCGCTGG $-3^{\prime}$ and reverse (5'-AGTTCCCATAGTTGCCAGGA-3') primers. The nucleotide sequences of these primers correspond to sequences 49-68 and 214-195 of human BET1 cDNA (NM_005868). The size of amplified fragment is $166 \mathrm{bp}$. The amplification of TRAPPC3 (trafficking protein particle complex 3), also known as BET3, cDNA was performed using two oligonucleotides primers: forward - 5'-GGCACCGAGAGCAAGAAAAT- $3^{\prime}$ and reverse - 5'CCAACATTTGACCGAGCCAA-3'. The nucleotide sequences of these primers correspond to sequences 158-177 and 333-314 of human TRAPPC3 cDNA (NM_014408). The size of amplified fragment is $176 \mathrm{bp}$.

The amplification of ENDOG (endonuclease G) cDNA was performed using two oligonucleotides primers: forward $-5^{\prime}-$ GTTCTACCTGAGCAACGTCG-3' and reverse 5'-TGCCGATGACCTGGTACTTT-3'. The nucleotide sequences of these primers correspond to sequences 659-678 and 843-824 of human ENDOG cDNA (NM_004435). The size of amplified fragment is $185 \bar{b}$ p. For amplification of POLG (DNA directed polymerase gamma) cDNA we used forward (5'-GATCTGGCCAATGATGCCTG-3' and reverse (5'-AAACTCCTCCTCCTCACTGC- $3^{\prime}$ ) primers. The nucleotide sequences of these primers 
correspond to sequences $1675-1694$ and 1899-1880 of human POLG cDNA (NM_002693). The size of amplified fragment is $225 \mathrm{bp}$.

The amplification of TSFM (Ts Mitochondrial Translational Elongation Factor) cDNA was performed using two oligonucleotides primers: forward - 5'-AAACCTTGAAGACGTTGGCC- $3^{\prime}$ and reverse - 5'-CTGCCTCTTCACCTTCTCCA-3'. The nucleotide sequences of these primers correspond to sequences 798-817 and 1021-1002 of human TSFM cDNA (NM_005726). The size of amplified fragment is $224 \bar{b}$ p. For amplification of MTIF2 (mitochondrial translational initiation factor 2) cDNA we used forward (5'-TGTGGAAGAGCACCCAGTAG $-3^{\prime}$ and reverse $\left(5^{\prime}-\right.$ AGACCACAATCCATTCCCGT $-3^{\prime}$ ) primers. The nucleotide sequences of these primers correspond to sequences 2167-2186 and 2397-2378 of human MTIF2 cDNA (NM_002453). The size of amplified fragment is $231 \mathrm{bp}$.

The amplification of $\beta$-actin (ACTB) cDNA was performed using forward - 5'-GGACTTCGAGCAAGAGATGG-3' and reverse - 5'-AGCACTGTGTTGGCGTACAG-3' primers. These primer nucleotide sequences correspond to 747-766 and 980-961 of human ACTB cDNA (NM_001101). The size of amplified fragment is $234 \mathrm{bp}$. The expression of $\beta$-actin mRNA was used as control of analyzed RNA quantity. The primers were received from Sigma-Aldrich (St. Louis, MO, USA).

Quantitative PCR analysis was performed using Differential Expression Calculator software. The values of IL13RA2, KRT18, CD24, ING1, ING2, MYRL2, BET1, TRAPPC3, ENDOG, POLG, TSFM, MTIF2, and ACTB gene expressions were normalized to the expression of $\beta$-actin mRNA and represented as percent of control (100\%). All values are expressed as mean \pm SEM from triplicate measurements performed in 4 independent experiments. The amplified DNA fragments were also analyzed on a $2 \%$ agarose gel and visualized by SYBR* Safe DNA Gel Stain (Life Technologies, Carlsbad, CA, USA).

Statistical analysis. Statistical analysis was performed according to Student's t-test using Excel program as described previously [39]. All values are expressed as mean \pm SEM from triplicate measurements performed in 4 independent experiments.

\section{Results and Discussion}

To determine if hypoxia affects the expression of a subset of genes encoding different proliferation related factors through the IRE1 branch of endoplas- mic reticulum stress response, we investigated the effect of hypoxic condition on the expression levels of these genes in control glioma cells (transfected by vector) and cells without both enzymatic activities of this signaling enzyme. As shown in Fig. 1, the expression levels of IL13RA2, CD24, ING1, ING2, ENDOG, and POLG mRNAs are significantly upregulated upon hypoxia. Thus, hypoxia leads to upregulation of the expression level of CD24 mRNA by $85 \%$, ING1 - by $146 \%$, and ENDOG - by $58 \%$ in glioma cells, but smaller changes were observed for ING2, POLG, and IL13RA2 genes $(+20,+15$, and $+15 \%$, respectively). At the same time, the expression levels of KRT18, TRAPPC3, TSFM, and MTIF2 mRNA are down-regulated by hypoxia in control glioma cells in comparison to normoxic cells (Fig. 1). The expression levels of TRAPPC3, TSFM, and MTIF2 mRNA are decreased by hypoxia by 24 , 25 , and $21 \%$, respectively. However, no significant changes were observed for BET1 and MYL9 genes in control glioma cells treated by hypoxia in comparison to normoxic cells (Fig. 1).

To investigate a possible role of endoplasmic reticulum stress signaling mediated by IRE1 signaling enzyme in regulation of the expression of studied proliferation related genes by hypoxia, we investigated the effect of hypoxic condition on gene expressions in glioma cells without both enzymatic activities of this signaling enzyme. As shown in Fig. 2, inhibition of the signaling enzyme IRE1 by dnIRE1 significantly modifies the effect of hypoxia on the expression level of half of the studied genes as compared to control glioma cells (Fig. 1). Thus, hypoxia up-regulates the levels of IL13RA2 $(+35 \%)$, ENDOG $(+110 \%)$, POLG $(+32 \%)$, and BET1 $(+17 \%)$ genes expression in glioma cells with knockdown of signaling enzyme IRE1 in comparison to normoxic cells. At the same time, inhibition of IRE1 enzyme leads to down-regulation of the expression levels of two other genes, ING1 and TRAPPC3 (Fig. 2). Furthermore, no significant changes were observed for next six genes (KRT18, CD24, ING2, MYL9, TSFM, and MTIF2) in glioma cells with knockdown of signaling enzyme IRE1 treated by hypoxia in comparison to normoxic cells (Fig. 2).

As a next step we tested the effect of inhibition of signaling enzyme IRE1 on a sensitivity of studied proliferation related genes expression to hypoxia (Fig. 3 and 4). For this, we analyzed the effect of hypoxic condition on the expression levels of IL13RA2, KRT18, CD24, ING1, ING2, MYL9, 


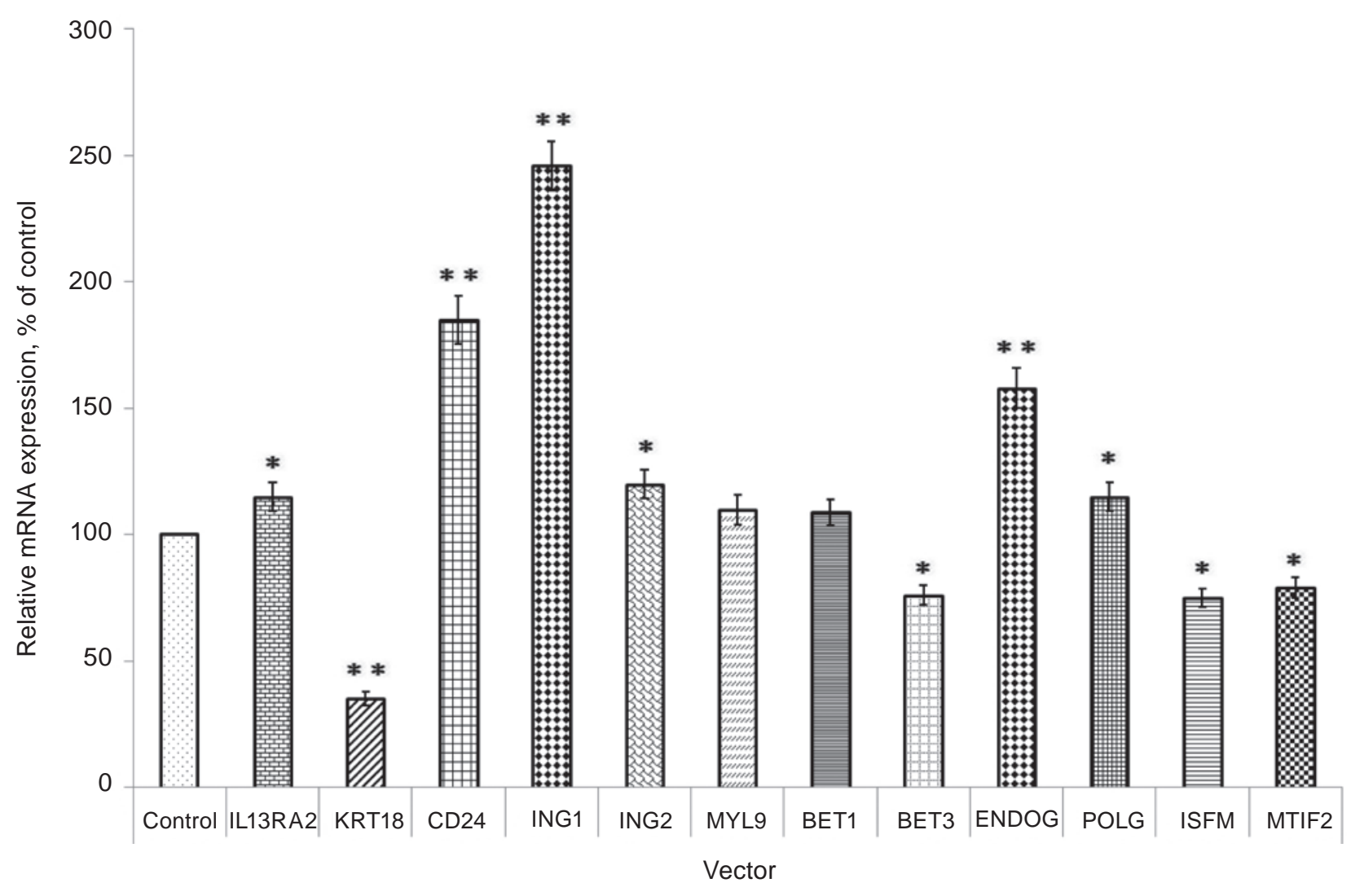

Fig. 1. Effect of hypoxia (3\% oxygen - $16 \mathrm{~h}$ ) on the expression levels of proliferation related genes in control U87 glioma cells (Vector) measured by qPCR. The values of IL13RA2, KRT18, CD24, ING1, ING2, MYL9, BET1, BET3/TRAPPC3, ENDOG, POLG, TSFM, and MTIF2 mRNA expressions were normalized to $\beta$-actin $m R N A$ level and presented as percent of control (100\%); $n=4 ; * P<0.05$ versus control; $* * P<0.01$ versus control

BET1, BET3/TRAPPC3, ENDOG, POLG, TSFM, and MTIF2 mRNA in glioma cells with functional IRE1 enzyme and inhibited IRE1 function in conditions when both controls (control glioma cells stable transfected by vector and glioma cells stable transfected by dnIRE1) are established as $100 \%$ in order to clarify the difference in the sensitivity of these gene expressions to hypoxia in respect to inhibition of IRE1 more precisely. As shown in Fig. 3, inhibition of the signaling enzyme IRE1 by dnIRE1 significantly modifies the effect of hypoxia on the expression levels of IL13RA2, KRT18, CD24, ING1, and MYL9 genes as compared to control glioma cells transfected by vector. Moreover, stronger changes in sensitivity to hypoxia were observed for KRT18, CD24, and ING1 genes: IRE1 inhibition almost completely eliminates the effect of hypoxia on these genes expression (Fig. 3).

Smaller but statistically significant changes in sensitivity to hypoxia of MYL9 gene expression were shown between control glioma cells and cells without signaling enzyme IRE1 function (Fig. 3). Moreover, inhibition of IRE1 enhances the effect of hypoxia on the expression of IL13RA2 gene and eliminates hypoxic regulation of MYL9 gene expression.

As shown in Fig. 4, inhibition of the signaling enzyme IRE1 by dnIRE1 also modifies the effect of hypoxia on the expression level of BET3/TRAPPC3, ENDOG, POLG, ISFM, and MTIF2 genes in U87 glioma cells as compared to control glioma cells transfected by vector. It was also shown that inhibition of IRE1 slightly modifies the effect of hypoxia on the expression of BET3/TRAPPC3 gene. At the same time, effect of hypoxia on the expression of ENDOG and POLG genes in glioma cells with IRE1 knockdown is greater than in control glioma cells: $+110 \%$ versus $+58 \%$ for ENDOG gene and $+32 \%$ versus $+15 \%$ for $P O L G$ gene (Fig. 4). It is also shown in Fig. 4 that inhibition of IRE1 signaling enzyme 


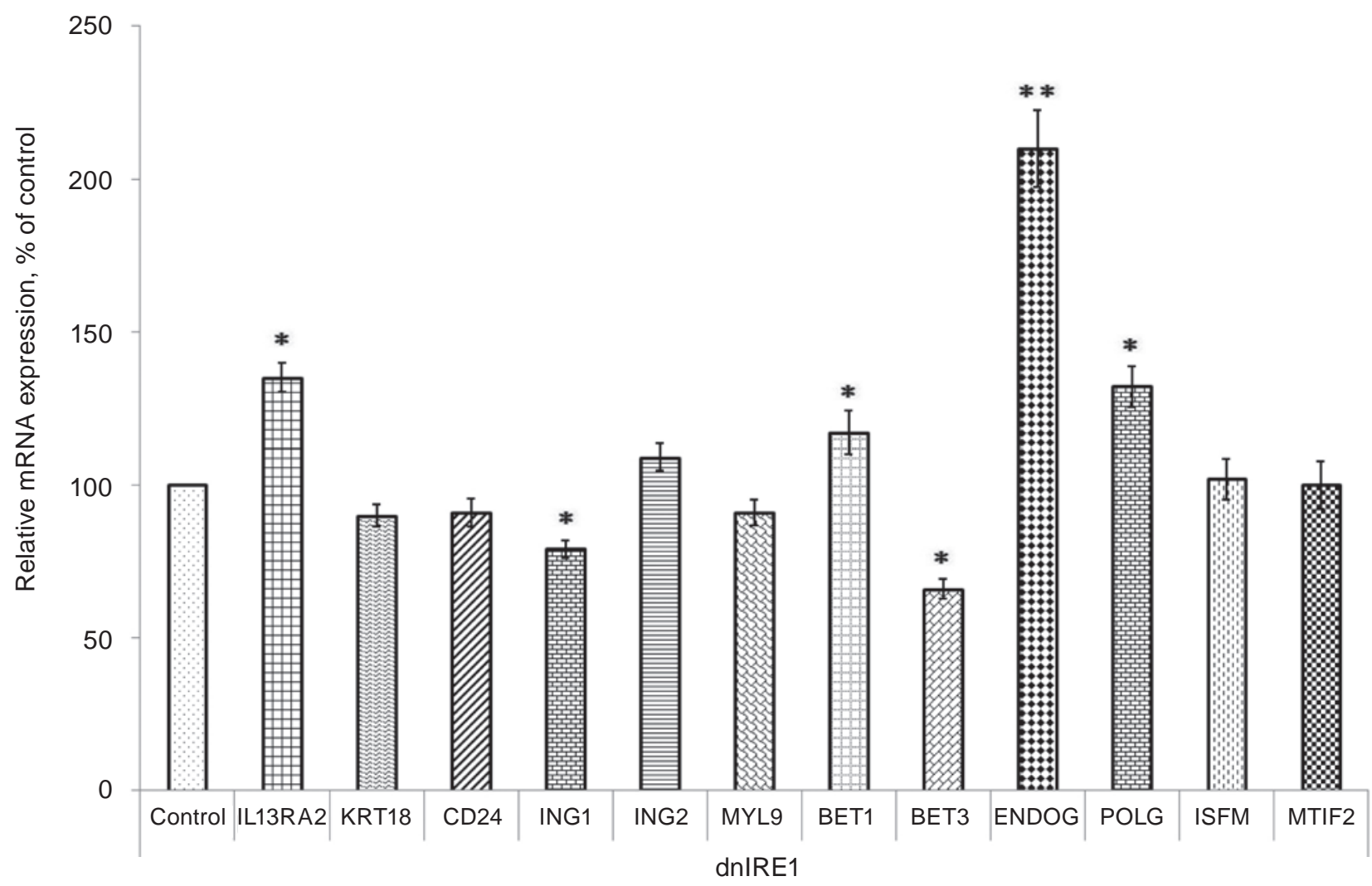

Fig. 2. Effect of hypoxia on the expression levels of proliferation related genes in U87 glioma cells with a blockade of the IRE1 by dnIRE1 (dnIRE1) measured by qPCR. The values of IL13RA2, KRT18, CD24, ING1, ING2, MYL9, BET1, BET3/TRAPPC3, ENDOG, POLG, TSFM, and MTIF2 mRNA expressions were normalized to $\beta$-actin mRNA level and presented as percent of control (100\%); $n=4 ; * P<0.05$ versus control; ** $P<0.01$ versus control

completely eliminates hypoxic regulation of TSFM and MTIF2 gene expressions.

In this work we studied the expression of a subset of genes encoding different proliferation related factors in U87 glioma cells with functionally active signaling enzyme IRE1 and cells with IRE1 knockdown upon hypoxia for evaluation of possible signifcance of these genes in the control of glioma growth through endoplasmic reticulum stress signaling mediated by IRE1 and hypoxia. Investigation of the expression of IL13RA2, KRT18, CD24, ING1, ING2, MYL9, BET1, BET3/TRAPPC3, ENDOG, POLG, TSFM, and MTIF2 genes in glioma cells upon hypoxia in respect to inhibition of IRE1 signaling is important for understanding of malignant tumor growth mechanisms, because hypoxia as well as endoplasmic reticulum stress play an essential role in the control of tumor progression [22, 35-38]. The growing tumor requires the endoplasmic reticulum stress and hypoxia for its own neovascularization and growth, for apoptosis inhibition [29,
30, 38]. Cell proliferation is strongly dependent on hypoxia and glycolysis because there is the molecular connection between cell cycle progression and the provision of substrates essential for this purpose $[35,37,38]$. In this study we demonstrated that the expression of most studied genes in control glioma cells is affected by hypoxia as compared to normoxic condition. The expression levels of IL13RA2, CD24, ING1, ING2, ENDOG, and POLG genes are increased upon hypoxia. To the contrary, the expression levels of several other genes (KRT18, TRAPPC3, TSFM, and MTIF2) are decreased. Our results are mostly consistent with numerous data [22, 23, 36-38] that hypoxia associated with malignant progression through the endoplasmic reticulum unfolded protein response, but mechanisms through which malignant cells cope with potentially lethal metabolic stress induced by hypoxia remain poorly understood.

We have shown that hypoxia significantly down-regulates the expression of anti-proliferative gene KRT18, which contributes to decreased ma- 


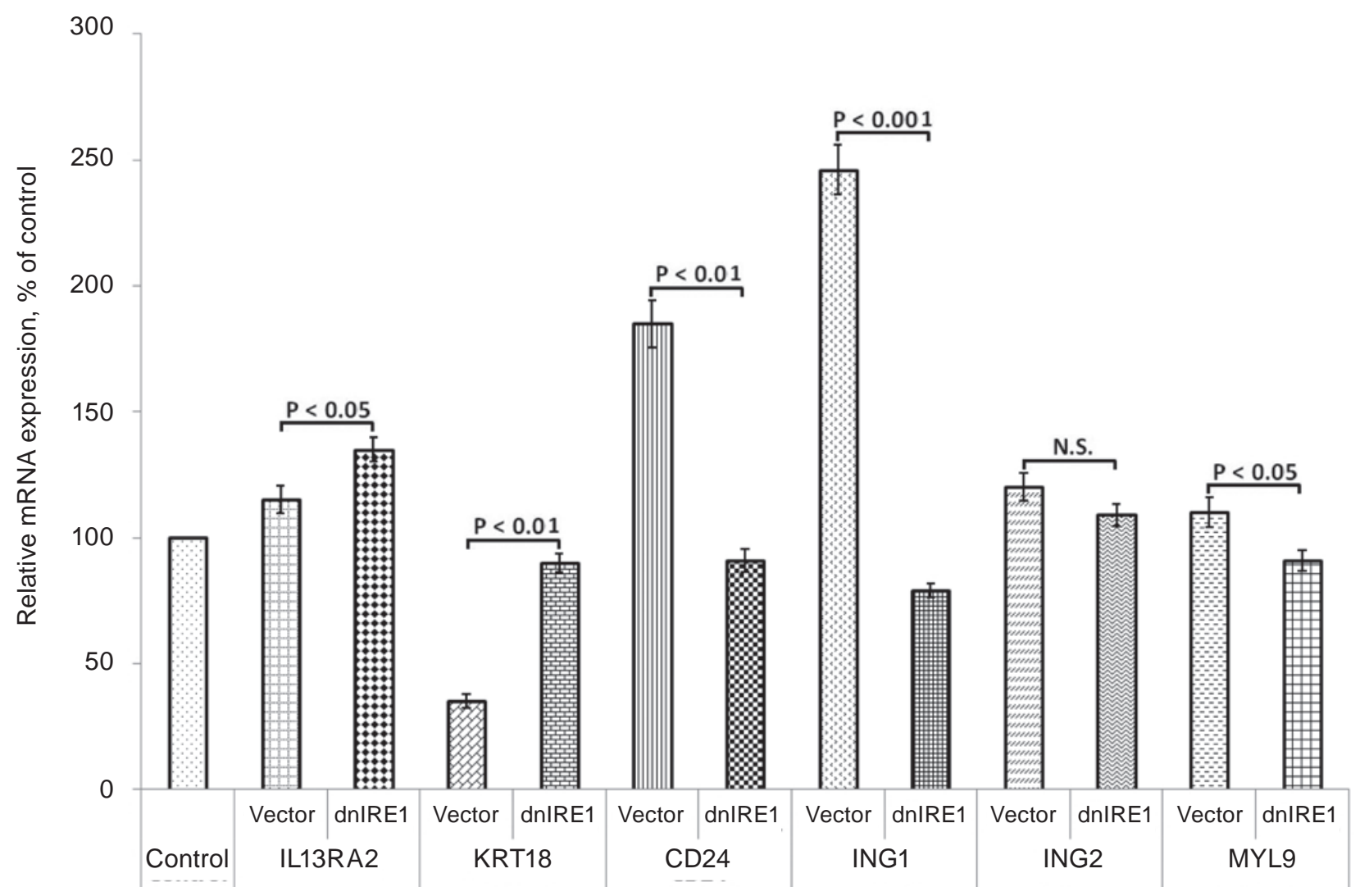

Fig. 3. Effect of hypoxia on the expression levels of IL13RA2, KRT18, CD24, ING1, ING2, and MYL9 mRNA in control U87 glioma cells (Vector) and cells with a blockade of the IRE1 by dnIRE1 (dnIRE1) measured by $q P C R$. Values of these $m R N A$ expressions were normalized to $\beta$-actin $m R N A$ level and presented as percent of control (100\%); $n=4$

lignancy of non-small cell lung carcinoma [11], in control glioma cells and that inhibition of IRE1 signaling eliminates this effect of hypoxia. Thus, in case of KRT18 gene, hypoxia may reveal the proproliferative effect and inhibition of IRE1 and consequent cell proliferation abolishes this effect of hypoxia. Furthermore, inhibition of IRE1 in glioma cells eliminates the effect of hypoxia on the expression of many other studied genes, such as CD24, ING2, TSFM, and MTIF2 genes and suppresses hypoxic regulation of ING1 and POLG genes. Similar results were obtained previously for TP53, ZMAT3, IGFBP6, IGFBP7, NOV, WISP2, and HOXC6 genes [36, 40, 41].
Therefore, present study demonstrates that hypoxia, which usually contributes to tumor growth, affects almost all studied genes expression and that inhibition of IRE1 can both enhance and suppress the hypoxic regulation of these gene expressions in gene specific manner and thus possibly contributes to slower glioma growth. However, the detailed molecular mechanisms of IRE1-mediated hypoxic regulation of these genes, which have a pivotal role in the control of cell proliferation, are complex and warrant further investigation. 


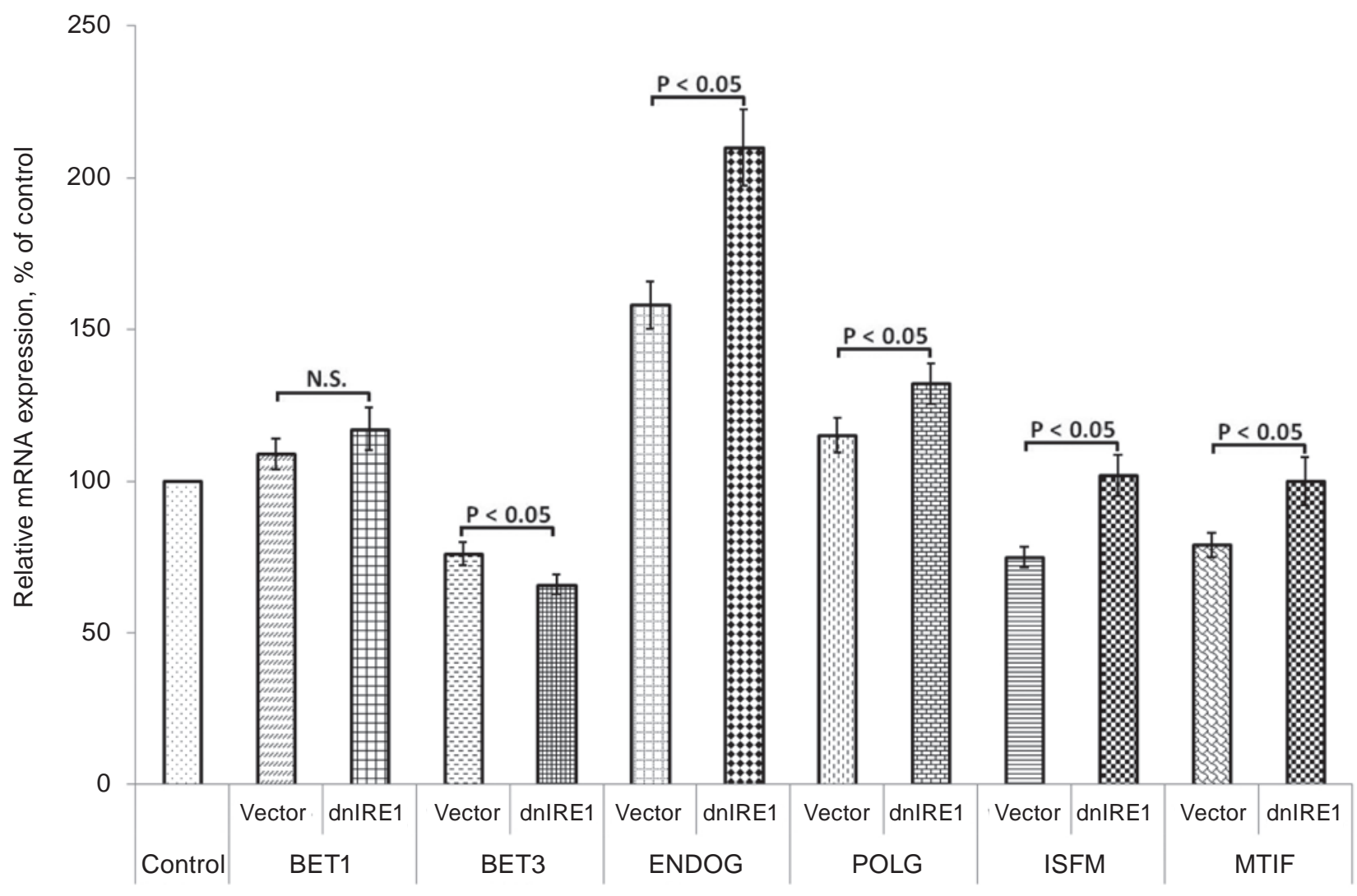

Fig. 4. Effect of hypoxia on the expression levels of BET1, BET3/TRAPPC3, ENDOG, POLG, ISFM, and MTIF mRNA in control U87 glioma cells (Vector) and cells with a blockade of the IRE1 by dnIRE1 (dnIRE1) measured by $q P C R$. Values of these $m R N A$ expressions were normalized to $\beta$-actin $m R N A$ level and presented as percent of control (100\%); $n=4$

\section{РЕГУЛЯЦІЯ ЕКСПРЕСІЇ ГЕНІВ, ЩО МАЮТЬ ВІДНОШЕННЯ ДО ПРОЛІФЕРАЦІЇ КЛІТИН, ЗА УМОВ ГІПОКСІї ТА ПРИГНІЧЕННЯ СИГНАЛЬНОГО ЕНЗИМУ IRE1 У КЛІТИНАХ ГЛІОМИ ЛІНІї U87}

\section{О. Г. Мінченко , Д. О. Цимбал \\ Д. О. Мінченко ${ }^{1,2}$, О. О. Рябовол 1 , \\ О. О. Ратушна 1 , Л. Л. Карбовський}

${ }^{1}$ Інститут біохімії ім. О. В. Палладіна НАН України, Київ; e-mail: ominchenko@yahoo.com;

${ }^{2}$ Національний медичний університет ім. О. О. Богомольця, Київ, Україна

Ми вивчали ефект пригнічення IRE1 (залежного від інозитолу ензиму 1), що є центральним медіатором стресу ендоплазматичного ретикулума і контролює проліферацію клітин та ріст пухлин, на гіпоксичну регуляцію експресії різних генів, які мають відношення до проліферації, у клітинах гліоми лінії U87. Встановлено, що за умов гіпоксії спостерігалося посилення експресії генів IL13RA2, CD24, ING1, ING2, ENDOG та POLG і зниження - генів KRT18, TRAPPC3, TSFM та MTIF2 на рівні мРНК у контрольних клітинах гліоми, причому більш виражені зміни виявлені для генів ING1 та CD24. Пригнічення IRE1 модифікувало ефект гіпоксії на експресію всіх досліджених генів: збільшувало чутливість до гіпоксії експресії генів IL13RA2, TRAPPC3, ENDOG та PLOG, знижувало ефект гіпоксії на ген ING1. Крім того, пригнічення IRE1 знімає регуляцію гіпоксією експресії генів KRT18, CD24, ING2, TSFM та MTIF2 і ініціює чутливість до гіпоксії експресії гена BET1 у клітинах гліоми. Результати цієї роботи продемонстрували, що гіпоксія (необхідний фактор росту пухлин), змінює рівень експресії майже всіх досліджених генів і що пригнічення IRE1 як посилює, так і знижує гіпоксичну регуляцію експресії цих генів i, та- 
ким чином, можливо, є внеском у зниження росту гліоми, але деякі аспекти цієї регуляції ще необхідно з'ясувати.

К л ючов і слов а: експресія мРНК, стрес ендоплазматичного ретикулума, IL13RA2, KRT18, CD24, ING1, ING2, MYL9, BET1, TRAPPC3, ENDOG, POLG, TSFM, MTIF2, пригнічення IRE1, гіпоксія, клітини гліоми.

\section{РЕГУЛЯЦИЯ ЭКСПРЕССИИ ГЕНОВ, ИМЕЮЩИХ ОТНОШЕНИЕ К ПРОЛИФЕРАЦИИ КЛЕТОК, ПРИ ГИПОКСИИ И УГНЕТЕНИИ СИГНАЛЬНОГО ЭНЗИМА IRE1 В КЛЕТКАХ ГЛИОМЫ ЛИНИИ U87}

О. Г. Минченко, Д. О. Цимбал
Д. О. Минченко,
О. О. О. Ратучинововол
, Л. Л. Карбовский

${ }^{1}$ Институт биохимии им. А. В. Палладина НАН Украины, Киев; e-mail: ominchenko@yahoo.com;

${ }^{2}$ Национальный медицинский университет им. А. А. Богомольца, Киев, Украина

Мы изучали эффект угнетения IRE1 (зависимого от инозитола энзима 1), который является центральным медиатором стресса эндоплазматического ретикулума, контролирует пролиферацию клеток и рост опухолей, на гипоксическую регуляцию экспрессии различных генов, имеющих отношение к пролиферации, в клетках глиомы линии U87. Установлено, что при гипоксии усиливается экспрессия генов IL13RA2, CD24, ING1, ING2, ENDOG и POLG и снижается - генов KRT18, TRAPPC3, TSFM и MTIF2 на уровне мРНК в контрольных клетках глиомы, причем более выраженные изменения выявлены для генов ING1 и CD24. Угнетение IRE1 модифицировало эффект гипоксии на экспрессию всех исследуемых генов, а именно увеличивало чувствительность к гипоксии экспрессии генов IL13RA2, TRAPPC3, ENDOG и PLOG и снижало эффект гипоксии на ген ING1. Кроме того, угнетение IRE1 снимает регуляцию гипоксией експрессии генов KRT18, CD24, ING2, TSFM и MTIF2 и инициирует чувствительность экспрессии гена BET1 к гипоксии в клетках глиомы. Результаты этой работы продемонстрировали, что гипоксия (необходимый фактор роста опухолей), изменяет уровень экспрессии почти всех исследованных генов. Угнетение IRE1 как усиливает, так и снижает регуляцию гипоксией экспрессии этих генов и, таким образом, возможно, вносит вклад в снижение роста глиомы, но некоторые аспекты этой регуляции еще необходимо выяснить.

Кл ючевы е слова: экспрессия мРНК, стресс эндоплазматического ретикулума, IL13RA2, KRT18, CD24, ING1, ING2, MYL9, BET1, TRAPPC3, ENDOG, POLG, TSFM, MTIF2, угнетение IRE1, гипоксия, клетки глиомы.

\section{References}

1. Saka M., Amano T., Kajiwara K., Yoshikawa K., Ideguchi M., Nomura S., Fujisawa H., Kato S., Fujii M., Ueno K., Hinoda Y., Suzuki M. Vaccine therapy with dendritic cells transfected with Il13ra2 mRNA for glioma in mice. J. Neurosurg. 2010; 113(2): 270-279.

2. Taguchi A., Taylor A. D., Rodriguez J., Celiktaş M., Liu H., Ma X., Zhang Q., Wong C. H., Chin A., Girard L., Behrens C., Lam W. L., Lam S., Minna J. D., Wistuba I. I., Gazdar A. F., Hanash S. M. A search for novel cancer/testis antigens in lung cancer identifies $\mathrm{VCX} / \mathrm{Y}$ genes, expanding the repertoire of potential immunotherapeutic targets. Cancer Res. 2014; 74(17): 4694-4705.

3. Barderas R., Bartolome R. A., FernandezAcenero M. J., Torres S., Casal J. I. High expression of IL-13 receptor alpha2 in colorectal cancer is associated with invasion, liver metastasis, and poor prognosis. Cancer Res. 2012; 72(11): 2780-2790.

4. Parlato M., Souza-Fonseca-Guimaraes F., Philippart F., Misset B., Adib-Conquy M., Cavaillon J. M. CD24-triggered caspasedependent apoptosis via mitochondrial membrane depolarization and reactive oxygen species production of human neutrophils is impaired in sepsis. J. Immunol. 2014; 192(5): 2449-2459.

5. Chen J., Tran U. M., Rajarajacholan U., Thalappilly S., Riabowol K. ING1b-inducible microRNA203 inhibits cell proliferation. Br. $J$. Cancer. 2013; 108(5): 1143-1148.

6. Huang Y. Q., Han Z. D., Liang Y. X., Lin Z. Y., Ling X. H., Fu X., Cai C., Bi X. C., Dai Q. S., Chen J. H., He H. C., Chen Y. R., Jiang F. N., Zhong W. D. Decreased expression of myosin light chain MYL9 in stroma predicts malignant 
progression and poor biochemical recurrencefree survival in prostate cancer. Med. Oncol. 2014; 31(1): 820.

7. Bose P., Thakur S., Thalappilly S., Ahn B. Y., Satpathy S., Feng X., Suzuki K., Kim S. W., Riabowol K. ING1 induces apoptosis through direct effects at the mitochondria. Cell Death Dis. 2013; 4: E788.

8. Liu J., Lin Y., Yang H., Deng Q., Chen G., He J. The expression of p33(ING1), p53, and autophagy-related gene Beclin1 in patients with non-small cell lung cancer. Tumour Biol. 2011; 32(6): 1113-1121.

9. Guo X. B., Jing C. Q., Li L. P., Zhang, L., Shi Y. L., Wang J. S., Liu J. L., Li C. S. Down-regulation of miR-622 in gastric cancer promotes cellular invasion and tumor metastasis by targeting ING1 gene. World J. Gastroenterol. 2011; 17(14): 1895-1902.

10. Thalappilly S., Feng X., Pastyryeva S., Suzuki K., Muruve D., Larocque D., Richard S., Truss M., von Deimling A., Riabowol K., Tallen G. The p53 tumor suppressor is stabilized by inhibitor of growth 1 (ING1) by blocking polyubiquitination. PLOS ONE. 2011; 6(6): E21065.

11. Zhang H., Chen X., Wang J., Guang W., Han W., Zhang H., Tan X., Gu Y. EGR1 decreases the malignancy of human non-small cell lung carcinoma by regulating KRT18 expression. Sci. Rep. 2014; 4: 5416.

12. Zhang T., Hong W. Ykt6 forms a SNARE complex with syntaxin 5, GS28, and Bet1 and participates in a late stage in endoplasmic reticulum-Golgi transport. J. Biol. Chem. 2001; 276(29): 27480-27487.

13. Zhdanov D. D., Fahmi T., Wang X., Apostolov E. O., Sokolov N. N., Javadov S., Basnakian A. G. Regulation of Apoptotic Endonucleases by EndoG. DNA Cell Biol. 2015;34(5):316-326.

14. Linkowska K., Jawień A., Marszałek A., Malyarchuk B. A., Tońska K., Bartnik E., Skonieczna K., Grzybowski T. Mitochondrial DNA Polymerase $\gamma$ Mutations and Their Implications in mtDNA Alterations in Colorectal Cancer. Ann. Hum. Genet. 2015; 79(5): 320-328.

15. Lee W., St John J. The control of mitochondrial DNA replication during development and tumorigenesis. Ann. N.Y. Acad. Sci. 2015; 1350: 95-106.
16. Le Roy F., Silhol M., Salehzada T., Bisbal C. Regulation of mitochondrial mRNA stability by RNase L is translation-dependent and controls IFNalpha-induced apoptosis. Cell Death Differ. 2007; 14(8): 1406-1413.

17. Swan E. J., Maxwell A. P., McKnight A. J. Distinct methylation patterns in genes that affect mitochondrial function are associated with kidney disease in blood-derived DNA from individuals with Type 1 diabetes. Diabet. Med. 2015; 32(8): 1110-1115.

18. Zhang X., Bian X., Kong J. The proapoptotic protein BNIP3 interacts with VDAC to induce mitochondrial release of endonuclease G. PLoS One. 2014; 9(12): e113642.

19. Wang S., Kaufman R. J. The impact of the unfolded protein response on human disease. $J$. Cell Biol. 2012; 197(7): 857-867.

20. Yadav R. K., Chae S. W., Kim H. R., Chae H. J. Endoplasmic reticulum stress and cancer. $J$. Cancer Prev. 2014;19(2):75-88.

21. Moenner M., Pluquet O., Bouchecareilh M., Chevet E. Integrated endoplasmic reticulum stress responses in cancer. Cancer Res. 2007; 67(22): 10631-10634.

22. Lenihan C. R., Taylor C. T. The impact of hypoxia on cell death pathways. Biochem. Soc. Trans. 2013; 41: 657-663.

23. Denko N. C. Hypoxia, HIF1 and glucose metabolism in the solid tumour. Nat. Rev. Cancer. 2008; 8(9): 705-713.

24. Bravo R., Parra V., Gatica D., Rodriguez A. E., Torrealba N., Paredes F., Wang Z. V., Zorzano A., Hill J. A., Jaimovich E., Quest A. F., Lavandero S. Endoplasmic reticulum and the unfolded protein response: dynamics and metabolic integration. Int. Rev. Cell. Mol. Biol. 2013; 301: 215-290.

25. Pluquet O., Dejeans N., Chevet E. Watching the clock: endoplasmic reticulum-mediated control of circadian rhythms in cancer. Ann. Med. 2014; 46(4): 233-243.

26. Hetz C., Chevet E., Harding H. P. Targeting the unfolded protein response in disease. Nat. Rev. Drug Discov. 2013; 12(9): 703-719.

27. Manié S. N., Lebeau J., Chevet E. Cellular mechanisms of endoplasmic reticulum stress signaling in health and disease. 3. Orchestrating the unfolded protein response in oncogenesis: an update. Am. J. Physiol. Cell Physiol. 2014; 307(10): C901-C907. 
28. Clarke H. J., Chambers J. E., Liniker E., Marciniak S. J. Endoplasmic reticulum stress in malignancy. Cancer Cell. 2014; 25(5): 563-573.

29. Drogat B., Auguste P., Nguyen D. T., Bouchecareilh M., Pineau R., Nalbantoglu J., Kaufman R. J., Chevet E., Bikfalvi A., Moenner M. IRE1 signaling is essential for ischemiainduced vascular endothelial growth factor-A expression and contributes to angiogenesis and tumor growth in vivo. Cancer Res. 2007; 67(14): 6700-6707.

30. Auf G., Jabouille A., Guérit S., Pineau R., Delugin M., Bouchecareilh M., Magnin N., Favereaux A., Maitre M., Gaiser T., von Deimling A., Czabanka M., Vajkoczy P., Chevet E., Bikfalvi A., Moenner M. Inositolrequiring enzyme 1alpha is a key regulator of angiogenesis and invasion in malignant glioma. Proc Natl Acad Sci USA. 2010; 107(35): 1555315558.

31. Auf G., Jabouille A., Delugin M., Guérit S., Pineau R., North S., Platonova N., Maitre M., Favereaux A., Vajkoczy P., Seno M., Bikfalvi A., Minchenko D., Minchenko O., Moenner M. High epiregulin expression in human U87 glioma cells relies on IRE1alpha and promotes autocrine growth through EGF receptor. BMC Cancer. 2013; 13: 597.

32. Acosta-Alvear D., Zhou Y., Blais A., Tsikitis M., Lents N. H., Arias C., Lennon C. J., Kluger Y., Dynlacht D. D. XBP1 controls diverse cell typeand condition-specific transcriptional regulatory networks. Mol. Cell. 2007; 27: 53-66.

33. Aragón T., van Anken E., Pincus D., Serafimova I. M., Korennykh A. V., Rubio C. A., Walter P. Messenger RNA targeting to endoplasmic reticulum stress signalling sites. Nature. 2009; 457(7230): 736-740.

34. Pluquet O., Dejeans N., Bouchecareilh M., Lhomond S., Pineau R., Higa A., Delugin M., Combe C., Loriot S., Cubel G., Dugot-Senant N., Vital A., Loiseau H., Gosline S. J., Taouji S., Hallett M., Sarkaria J. N., Anderson K., Wu W., Rodriguez F. J., Rosenbaum J., Saltel F., Fernandez-Zapico M. E., Chevet E. Posttranscriptional regulation of PER1 underlies the oncogenic function of IRE $\alpha$. Cancer Res. 2013; 73(15): 4732-4743.

35. Chesney J., Clark J., Klarer A. C., ImbertFernandez Y., Lane A. N., Telang S. Fructose-2,6bisphosphate synthesis by 6-phosphofructo-2- kinase/fructose-2,6-bisphosphatase 4 (PFKFB4) is required for the glycolytic response to hypoxia and tumor growth. Oncotarget. 2014; 5: 66706686.

36. Minchenko D. O., Danilovskyi S. V., Kryvdiuk I. V., Bakalets T. V., Lypova N. M., Karbovskyi L. L., Minchenko O. H. Inhibition of ERN1 modifies the hypoxic regulation of the expression of TP53-related genes in U87 glioma cells. Endoplasm. Reticul. Stress Dis. 2014; 1(1): 18-26.

37. Minchenko O. H., Tsymbal D. O., Moenner M., Minchenko D. O., Kovalevska O. V., Lypova N. M. Inhibition of the endoribonuclease of ERN1 signaling enzyme affects the expression of proliferation-related genes in U87 glioma cells. Endoplasm. Reticul. Stress Dis. 2015; 2(1): 18-29.

38. Minchenko O. H., Kharkova A. P., Bakalets T. V., Kryvdiuk I. V. Endoplasmic reticulum stress, its sensor and signaling systems and the role in the regulation of gene expressions in malignant tumor growth and hypoxia. Ukr. Biochim. J. 2013; 85(5): 5-16.

39. Bochkov V. N., Philippova M., Oskolkova O., Kadl A., Furnkranz A., Karabeg E., Afonyushkin T., Gruber F., Breuss J., Minchenko A., Mechtcheriakova D., Hohensinner P., Rychli K., Wojta J., Resink T., Erne P., Binder B. R., Leitinger N. Oxidized phospholipids stimulate angiogenesis via autocrine mechanisms, implicating a novel role for lipid oxidation in the evolution of atherosclerotic lesions. Circ. Res. 2006; 99(8): 900-908.

40. Minchenko O. H., Kharkova A. P., Minchenko D. O., Karbovskyi L. L. Effect of hypoxia on the expression of genes that encode some IGFBP and CCN proteins in U87 glioma cells depends on IRE1 signaling. Ukr. Biochem. J. 2015; 87(6): 52-63.

41. Minchenko O. H., Tsymbal D. O., Minchenko D. O., Kovalevska O. V., Karbovskyi L. L., Bikfalvi A. Inhibition of ERN1 signaling enzyme affects hypoxic regulation of the expression of E2F8, EPAS1, HOXC6, ATF3, TBX3 and FOXF1 genes in U87 glioma cells. Ukr. Biochem. J. 2015; 87(2): 76-87.

Received 10.02.2016 